SUSTAINABLE FORESTRY

COLLECTION 70-71, 2015
ODRŽIVO ŠUMARSTVO

ZBORNIK RADOVA 70-71, 2015

UDK $630 * 844.2: 582.28=111$

Original scientific paper

\title{
REDUCTION THE MECHANICAL PROPERTIES OF OAKWOOD UNDER THE INFLUENCE OF EPYXILOUS FUNGUS
}

\author{
Miroslava MARKOVIC ${ }^{1}$, Snezana RAJKOVIC ${ }^{1}$, Ljubinko RAKONJAC ${ }^{1}$
}

\begin{abstract}
Within the scope of field research on diagnostics of harmful organisms in Serbia in the year 2015, in the area of Forest Estate Boljevac, the presence of epixylous fungus Coniophora puteana (Schumm. ex Fr.) Karst was found on dead oak trees following the icebreak. In order to give a more accurate forecast of prospective spread of the pathogen, i.e. determine the speed of the process, the laboratory of the Institute for Forestry conducted the testing of the rate of reduction of the oak tree modulus of elasticity after 2, 4 and 6 months of exposure to the fungus. Testing samples were collected from the medulla of healthy oak trees, from the association of Quercetum montanum. Over the periods of 2, 4 and 6 months the wood samples were exposed to influence of the mycelia of the fungus Coniophora puteana (Schumm. ex Fr.) Karst. After 2, 4 and 6 months under the effect of the fungus, the static modulus of elasticity of oak wood substantially decreased compared to the initial value (100\%) and amounted to $61.07 \%, 60.61 \%$ and $51.38 \%$ respectively. The regression line obtained through data processing opened the possibility to prognosticate the changes of wood properties in certain time periods of the effect of the fungus under the unchanged external conditions, which is significant for practical purposes in terms of taking protective measures and wood usability.
\end{abstract}

Key words: Modulus of Elasticity, Coniophora puteana

\footnotetext{
${ }^{1}$ Институт за шумарство, Београд, Србија. E-mail: mira013@gmail.com

ACKNOWLEDGMENTS: The study was carried out within the Project TR-31070: "The development of technological methods in forestry in order to attain optimal forest cover", financed by the Ministry of Education and Science of the Republic of Serbia within the framework of integrated and interdisciplinary research for the period $2011-2015$.
} 


\title{
СМАҢЕЊЕ МЕХАНИЧКИХ СВОЈСТАВА ДРВЕТА ХРАСТА ПОД УТИЦАЈЕМ ЕПИКСИЛНИХ ГЈИВА
}

\author{
Мирослава МАРКОВИЋ, Снежана РАЈКОВИЋ, \\ Љубинко РАКОЊАЦ
}

\begin{abstract}
Извод. У оквиру теренских истраживања на пословима дијагностике итетних организама у Србији у 2015. години, на подручју ШГ Бољеваи, на мртвом дрвету храста после ледолома, констатовано је присуство епиксилне гљиве Coniophora puteana (Schumm. ex Fr.) Karst. Да ширења овог патогена, односно утврдила брзина тог прочеса, у лабораторији Института за шумарство, извршена су испитивања брзине смањења једног механичког својства дрвета (чврстоће на савијање) након 2, 4 и 6 месеци излагања дејству ове гљиве. Испитивања су вршена на здравом дрвету храста из асочијаџије Quercetum montanuт, након 2, 4 и 6 месеци излагања дејству Coniophora puteana (Schumm. ex Fr.) Karst. После 2, 4 и 6 месеци дејства гљиве, статичка чврстоћа на савијање храста у односу на иницијалне вредности (100\%) износи 61,07\%, 60,61\% и 51,38\%. Регресиона линија отвара могућност прогнозе промене својстава дрвета у одређеном времену дејства под утииајем гљива, при непромененим условима спољне средине, ито је веома значајно у практичној примени, особито приликом заштите дрвета у ичиљу очувања његове употребне вредности.
\end{abstract}

Кључне речи: чврстоћа на савијање, Coniophora puteana

\section{INTRODUCTION}

Development of the wood processing industry is causing growing demand for high-quality wood raw materials [14, 18]. This calls for preservation and extension of wood durability, which is directly linked to preservation of physical, chemical, mechanical, aesthetical and other properties, according to several authors $[7,8,15,21]$. Basic structural constituents of wood (cellulose, hemicellulose and lignin) are distributed in different percentages in different species and parts of trees. There is thus more cellulose in soft than hard species of trees, in bolewood more than in branchwood, in early successional species more than in late ones, as discussed by Miric and Popovic [16].

Oak as a host is colonized by a large number of microorganisms, where a special place belongs to the research on impact of fungi, particularly those attacking the core (srcika) as the technically most valuable part of a tree $[1,3,4]$. Through its enzyme system, the epixylous fungi break down the constituents of wood cell walls, modify the percentage of their participation and thus directly induce changes of the wood properties $[2,6,11]$. The agents of brown prismatic rot (to which the researched fungus $C$. puteana belongs) disintegrate primarily cellulose, while the disintegration of lignin occurs in a far smaller extent.

This paper presents the course of alteration (decrease) of the presence of lignin in the cell wall, reflected in the decrease of wood bulk modulus of $Q$. petraea agg. under the influence of the fungus $C$. puteana after 2, 4 and 6 months of the incubation $[26,20,17]$. 


\subsection{Basic Biological Features of the Fungus $C$. puteana}

C. puteana most frequently occurs in humid rooms, such as basements, which is how it got its colloquial name. It often occurs in mines, warhouses, bridge constructions, pillars, attacking the timber of both coniferous and broadleaved species. It causes quick rot on decumbent trees that are not properly insulated. $C$. puteana is a saprophyte and the most widely distributed fungus in America and Europe causing wood decay in buildings, second only to Merulius lacrymans (Jacq.) Fr. (Syn. Serpula lacrymans Wulfen Fr.).

According to reference sources, the percentage of rot caused by this fungus in buildings in Europe has risen sharply over the last several years [19, 18]. This might be a consequence of a hard struggle against this fungus, given that it its highly resistant to antiseptics and hence among the organisms used in testing biological efficiency of wood protection agents. In forests it occurs on dead, fallen trees, causing typical brown rot which in the final stages of decomposition turns the tree almost black. Sometimes the rot may develop only in the inner part of timber so that the surface layers remain more or less intact. Cracks in trees caused by exposure to C. puteana are somewhat milder in the cross section, and although the tree does not disintegrate like under the influence of M. lacrymans, it does turn so fragile and brittle that it breaks when touched. In addition to carpophores, fanlike mycelia with thin black rhizomorphs invariably forms on the surface of trees, making the symptoms of attack easily noticeable [19].

\section{MATERIAL AND METHOD}

The substrate used in the research was a 110-year-old healthy tree of Sessile oak Q. petraea agg., $19 \mathrm{~m}$ tall and $35 \mathrm{~cm}$ in diameter at breast height. The tree had been cut in Eastern Serbia, at the altitude of $550 \mathrm{~m}$, on the southern exposition and in association Quercetum montanum [25]. The analyses were conducted on a $\log 3.5 \mathrm{~m}$ in length (from the lower part of the trunk to the first live branch), which was according to the relevant pattern cut into specimens using the standard prescribed dimensions $2 \times 2 \times 32 \mathrm{~cm}$. The fronts of specimens were smeared with antiseptic paste so as to prevent penetration of hyphae from that direction, given the small dimensions of the specimens representing a large beam used for practical purposes. Since the development of cross-section hyphae is the fastest, if the penetration of hyphae was enabled from that side, the small specimens would quickly rot and the relevant results would not be obtained.

The specimens were dried in a classic drying chamber at the temperature of $103 \pm 1{ }^{\circ} \mathrm{C}$ and measured with the accuracy of $0.01 \mathrm{~g}$. On control specimens (healthy wood), the modulus of elasticity was measured on universal machine for testing wood properties $[23,24]$. The specimens to be exposed to the mycelia were conditioned at approximately $12 \%$ humidity. Mycelia C. puteana was resown into plastic Petri dishes containing malt-agar growing medium of standard concentration. The experiment used sterilized plastic vessels with lids into which Petri dishes with fully developed mycelia $C$. puteana were placed. The petri dishes 
served as glass carriers ( dimensions $9 \times 22 \times 35 \mathrm{~cm}$ ) in order to prevent excessive soaking of moisture from the growing medium, onto which wood specimens of Sessile oak were placed. On the top of the stack were petri dishes with $5 \%$ water solution of boric acid intended to induce high relative air humidity.

The dishes were kept in a closed sterilized chamber in the total darkness, and the temperature was controlled by thermograph throughout the experiment. Over most of the duration of the research the temperature in the chamber was at about $20^{\circ} \mathrm{C}$, with brief time intervals at about $28^{\circ} \mathrm{C}$, which are roughly optimal temperatures for the development of the researched species. Upon the expiration of the relevant period of incubation (2, 4 and 6 months), the specimens were taken out of the dishes, cleaned from the surface mycelia, dried in a classic drying chamber at the temperature of $103 \pm 1^{\circ} \mathrm{C}$.

By definition, modulus of elasticity is the resistance of a tree to the effect of concentrated, evenly distributed or combined forces that strive to bend or distort it. Therefore, the bending pressure is a complex strain consisting of a thrust pressure in the part of the carrier closer to the action point and the strain pressure at the opposite side. Between these two zones there is a neutral axe which under the impact of the load moves towards the side of the strain pressure [22]. Given that the flexural strength is calculated relative to the cross section of a tree at the point of effect of the force, before measuring the strength all test tubes were measured across the middle using a micrometer, with the accuracy of $0.01 \mathrm{~mm}$. The distance between braces was $280 \mathrm{~mm}$, while the test tubes were exposed to the action of a single concentrated force in the middle of the distance between braces. Modulus of elasticity investigated with machine for the testing wood properties (TIRA test 2300 ) with a rotund force transfer suppressor and a $15 \mathrm{~mm}$ radius. The speed of the action of force was uniform, in the total duration of approximately 2 minutes. All data obtained were processed by applying the standard statistical methods; destruction results were compared using the single factor analysis of variance and the least significant difference test for the control group and the duration of the fungus impact (2, 4 and 6 months).

Statistical data processing was done on absolute amounts - N/mm $\mathrm{mm}^{2}$, while a correlation analysis was performed in order to prove the existence of a link between the time of action of the fungus as the independent variable and change of modulus of elasticity as the dependent variable.

\section{RESULTS AND DISCUSSION}

During the course of their development, the epixilous fungi feeding on basic constitutional components of the tree alter not only its chemical composition but also its entire inner structure, which results in a change, i.e. decrease in its mechanical, physical, aesthetical and other properties. Brown rot agents in wood cause analogous chemical changes created during the hydrolysis of the tree by mild acids [20]. Through metabolic processes, fungi modify the nutritious matter down to the molecules suitable to their own life functions.

In order to analyze the changes of wood properties under the influence of epixilous fungi, it is necessary to provide a brief explanation of the fungi's need for 
nutrients, chemical composition of the tree, as well as changes that occur in the chemical composition and tree structure under their influence. All wood-decay fungi are able to use finished products such as free sugars, lipids, peptides and other primary metabolites. These substances have a crucial impact in the initial phase of tree colonization. Carbohydrates are the most significant source of carbon in nutrition of the epixilous fungi. A rich source of carbon lies in the basic structural elements of the wood cell walls (hemicellulose, cellulose and lignin). Cellulose, which is the most widely present element on earth, builds the skeletal substance of the cell wall and represents the most important constituent of wood. The fungus $C$. puteana in a tree dissolves primarily cellulose (over $50 \%$ ), as well as lignin but to a far lesser degree (approximately 10\%) $[9,12]$.

Dissolution of cellulose does not occur evenly throughout the affected tree, since hyphae are individual and unorganized. Thus only a few cells are attacked at first, but their number gradually rises [13]. Moreover, dissolution of cellulose goes quickly at first and later on slows down, which is a consequence of the effect of the fungus that first demolishes the free cellulose in the middle layer of the secondary wall, given that this layer has virtually no impregnation with lignin. As soon as the fungus gets into the parts of cellular membrane with a higher lignin content, the dissolution slows down, so that the dissolution of cellulose in the primary wall is the slowest, as this is where the largest portion of total lignin is incorporated [5]. Changes of the tree structure are reflected primarily in the modulus of elasticity, with the process being roughly 2 to 3 times faster in brown rot agents. Basic parameters of the modulus of elasticity of $Q$. petraea agg. samples that were exposed to the effect of the species C. puteana for 2, 4 and 6 months compared to the control are presented in table 1 and expressed in absolute values.

Table 1. Modulus of elasticity Reduction (\%) under the Influence of the Fungus C. puteana

\begin{tabular}{||l||c|c|c|c||}
\hline \hline & 0 months & $\begin{array}{c}2 \\
\text { months }\end{array}$ & 4 months & 6 months \\
\hline \hline Number of measurements & 30 & 30 & 29 & 30 \\
\hline Minimum amount & 109.74 & 47.76 & 50.64 & 29.11 \\
\hline Maximum amount & 205.98 & 146.98 & 138.12 & 120.96 \\
\hline Arithmetic mean & $\mathbf{1 5 6 . 1 2}$ & $\mathbf{9 5 . 3 4}$ & $\mathbf{9 4 . 6 2}$ & $\mathbf{8 0 . 2 1}$ \\
\hline Standard deviation & 28.65 & 27.44 & 21.90 & 25.52 \\
\hline Variation coefficient & 18.35 & 28.78 & 23.15 & 31.82 \\
\hline
\end{tabular}

The table 1 demonstrates that the smallest dissipation of data (variation coefficient) occurs in the control group of samples (18.35), while the highest is after 2 and 6 months of exposure to the species C. puteana (28.78 and 31.82), which is a consequence of non-homogenous tree structure and uneven colonization of the tree by the fungus. The average modulus of elasticity amounts to 156.12 in the control group of samples, 95.34 after 2 months of exposure to fungus $C$. puteana, 94.62 after 4 months, and $80.21 \mathrm{~N} / \mathrm{mm}^{2}$ after 6 months of exposure. The percentage of decrease of the modulus of elasticity of $Q$. petraea agg. under the influence of the species $C$. puteana, compared to the control, is presented in table 2. 
Table 2. Differences in modulus of elasticity of trees (\%) exposed to fungus $C$. puteana

\begin{tabular}{||c||c|c|c|c|}
\hline Period of exposure & 0 months & 2 months & 4 months & 6 months \\
\hline \hline $\begin{array}{c}\text { Modulus of } \\
\text { elasticity(\%) }\end{array}$ & 100.00 & 61.07 & 60.61 & 51.38 \\
\hline \hline \multirow{2}{*}{$\begin{array}{c}\text { Difference of } \\
\text { modulus of elasticity } \\
(\%)\end{array}$} & 38.93 & 0.46 & 9.23 \\
\cline { 2 - 5 } & 39.39 & & \\
\cline { 2 - 4 } & \multicolumn{3}{|c|}{48.62} \\
\hline
\end{tabular}

On the basis of results presented in table 2, it is clear that the greatest decrease of the modulus of elasticity occurs in the first 2 months, i.e., in this period the modulus of elasticity drops by $38.93 \%$ compared to the control. In the period between months 2 and 4, the process of destruction (decrease of the modulus of elasticity) slows down and the loss amounts to only $0.46 \%$. In the period between months 4 and 6 the destruction mildly rises and the modulus of elasticity drops by another $9.23 \%$.

Therefore, the greatest decrease of the modulus of elasticity of $Q$. petraea agg. exposed to the fungus $C$. puteana occurs during the first 2 months, after which the process slows down. According to Rayner and Boddy [20], changes of tree properties under the influence of most brown rot agents are primarily reflected in changes of the modulus of elasticity and occur immediately following the appearance of first signs of rot, which is in this case particularly evident. Based on results of T- test, shown in table 3 , it is clear that significant differences occur as early as first 2 months of the influence of the fungus $C$. puteana and apply to all tested sample groups, except for the period between months 2 and 4.

Table 3. Modulus of elasticity Reduction under the Influence of C. puteana (T test)

\begin{tabular}{|l||c|c|c|c|}
\hline & 0 months & 2 months & 4 months & 6 months \\
\hline \hline 0 months & - & 60.7787 & 61.4962 & 75.9107 \\
\hline 2 months & & - & 0.717529 & 15.1320 \\
\hline 4 months & & & - & 14.4145 \\
\hline 6 months & & & & - \\
\hline
\end{tabular}

- Significant difference at the level of 0.05

This means that over this period there is no significant loss of the modulus of elasticity, with the differences being only the consequence of high variability of data, not exposure to the fungus. Based on the analysis of breakages of test tubes of Sessile oak exposed to C. puteana during the process of measuring the modulus of elasticity, it was found that in the first 2 months a large number of test tubes had smooth breakages in addition to short-fiber ones. Kruzsik [10] states that a tree with a higher modulus of elasticity has a long-fiber breakage, with a medium modulus short-fiber breakage, and with a low modulus a smooth breakage.

Table 4. Correlation analysis of Exposure time to Fungus and Wood Properties 


\begin{tabular}{|c||c|c|c||}
\hline Tested property & Model type & $\begin{array}{c}\text { Correlation coefficient } \\
(\mathrm{r})\end{array}$ & Regression equation \\
\hline \hline $\begin{array}{c}\text { Modulus of elasticity } \\
\left(\sigma_{\mathrm{s}}\right)\end{array}$ & $\begin{array}{c}\text { Square function } \\
(\mathrm{x})\end{array}$ & $\pm 0,967378$ & $\sigma_{\mathrm{s}}=151,514 \pm 30,6573 \times \sqrt{\mathrm{T}}$ \\
\hline
\end{tabular}

The obtained results lead to conclusion that after 6 months of exposure to the fungus the process of destruction of the tree, although highly advanced, is probably not completed, meaning that there is a possibility that the cell membrane layers may still contain the sufficient quantity of cellulose that provides the modulus of elasticity. Correlation analysis was performed in order to establish a correlation link between the tested tree properties depending on the time of exposure to the fungus (Tab. 4).

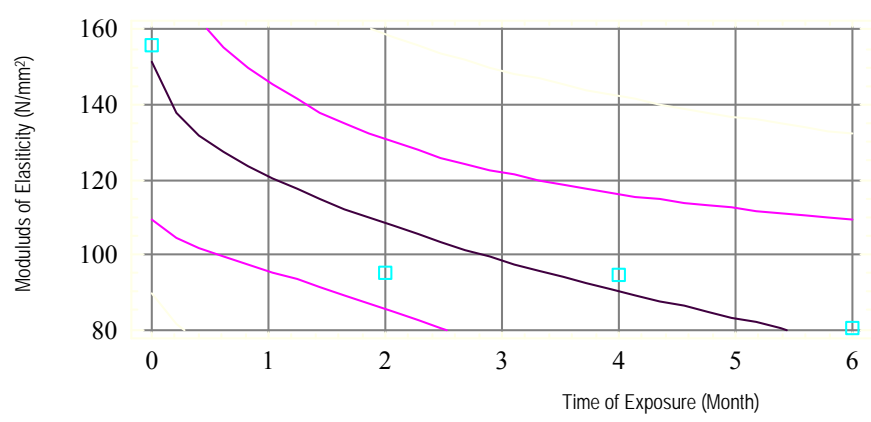

Figure 1. Regression lines decrease Modulus of elasticity Reduction of wood Q. petraea in dependent exposed time C. puteana

The performed correlation analysis of changes in wood properties $Q$. petraea agg. depending on the time of exposure to fungus $C$. puteana leads to conclusion that there is a strong correlation link between the variables. The regression line presented in picture 1 makes it possible to predict changes in wood properties over certain time periods of exposure to fungus, at unchanged environmental conditions.

This is significant for the purposes of practical application, i.e. for protection measures and wood utility. According to literature sources $[18,20]$ this property represents the quickest and clearest indication of destruction under the influence of epixilous fungi. To this effect, appropriate chemical analyses of wood exposed to influence of fungi could provide a clearer definition from both qualitative and quantitative aspect, allowing a comprehensive insight into the course and consequences of development of fungi in trees.

\section{CONCLUSIONS}


Based on the research presented, the following most relevant conclusions can be inferred:

After 2, 4 and 6 months under the effect of the fungus C. puteana, the static modulus of elasticity of oak wood substantially decreased compared to the initial value $(100 \%)$ and amounted to $61.07 \%, 60.61 \%$ and $51.38 \%$ respectively. In the period between 2 and 4 months the process of destruction slowed down and the loss amounted to only $0.46 \%$. In the period between the months 4 and 6 the destruction mildly rose and the modulus of elasticity dropped by another $9.23 \%$.

Correlation analysis showed a strong correlation link between the changes (decrease) in wood properties of $Q$. petraea agg. and the time of the influence of the fungus $C$. puteana. This opens the possibility to use the regression equation in forecasting modifications in wood properties, depending on the time of exposure to a fungus, under unchanged environmental conditions.

If a future research would carry out similar experiments on our most significant tree species against the greatest and most dangerous wood destructors, over a larger number of monitoring periods, the obtained results could serve as basis for creation of relevant tables (standards). By cross-referencing the obtained data and conducting their statistical analysis, we would arrive at the closest approximation of values to be inserted into relevant tables and applied in practice.

\section{REFERENCES}

[1] Brown MA, Zhao Z, Mauk AG (2002). Expression and characterization of a recombinant multi-copper oxidase: laccase $I V$ from Trametes versicolor. Inorg Chim Acta; 331: 232-238.

[2] Chu KKW, SS Ho and AH Chow (2002). Coriolus versicolor: a medicinal mushroom with promising immunotherapeutic values, Journal of Clinical Pharmacology, 42: 967-984

[3] Darrel DN (1985). Wood deterioration and its Prevention by preserve Treatments, University Press, Syracuse, New York, p 381

[4] David OM, Fagbohun ED, Oluyege AO and Adegbuyi A (2012). Antimicrobial activity and physicochemical properties of oils from tropical macrofungi, Journal of Yeast and Fungal Research Vol. 3(1), pp. 1-6

[5] Jankovský L, Vágner A, Apltauer J (2002). The decomposition of wood mass under conditions of climax spruce stands and related mycoflora in the Krkonose Mountains, Journal of Forest Science, 48 (2): 70-79

[6] Karadzic D and Andjelic M (2002). The most common wood decay fungi in forests and wood repositories, Monograph, Montenegrian Center for Forest Improvements, Podgorica, 120 - 154 pp [In Serbian].

[7] Karadzic, D (2006) "Influence of the parasitic fungi on the health condition of the Sessile oak, Hungarian oak and Turkey oak trees in natural forests and urban areas", Forestry, July - October, pp. 47-60

[8] D. Karadzic, D (2010). "Forest Phytopathology", Belgrade, Planet Print, p. 774

[9] Knezevic, M (1975). "Mechanical wood processing". Construction Book, Belgrade, p. 184

[10] Krzusik, F (1974): "Nauka o drevnie", Warszawa 
[11] Lee S, Bae H, Kim N, Hwang S (2008). Optimization of Growth Conditions of Lentinus edodes Mycelium on Corn Processing Waste Using Response Surface Analysis, J. Biosci. Bioeng. Soc. Biotechnol Jap., 105(2): 161-163.

[12] Markovic, M, Rajkovic, S, Miric, M, Mitic, D, Milovanovic, J, Tabakovic-Tosic, M (2011a). "Colonization of the substrate of wood - decaying fungi Fomitopsis pinicola (Sw.:Fr.) P. Karst. isolated from beech and fir under controlled temperature and pH conditions", Fresenius Environmental Bulletin, vol 20, no 3, pp. 583-589, 2011.

[13] Markovic, M, Rajkovic, S, Miric, M, Mitic, D, Rakonjac, Lj (2011b). "Growth conditions of mycelium medicinal mushroom Lentinula edodes (Berk.) Pegl. in the substrate colonization phase", Scientific Research and Essays, 8 September, vol 6 (19), pp. 4133-4140

[14] Miric, M, Schmidt, O (1992). "Nutrition some stereoid mushrooms", Journal of Faculty of Forestry, No. 74th, University of Belgrade, Belgrade, pp. $111-115$

[15] Miric, M (1993). The most important bio-ecological studies of fungi in the genus Stereum, challenger rot of oak wood, Ph.D. Thesis, Faculty of Forestry, Belgrade, pp. 120 [In Serbian].

[16] Miric M, Popovic Z (1993). Influence of Pleurotus ostreatus (Jacq.) Fr. and Trametes versicolor (L. ex Fr.) Pilat. the loss of hardness, compressive strength and mass of beech wood, Lumber Bulletin No. 6-7, Belgrade, pp 36-40 [In Serbian].

[17] Miric M (2005). Impact of stereoide fungi on decomposition of oak wood and possibility of its protection. Bulletin of the Faculty of Forestry, Issue 91, pp 31-61 [In Serbian].

[18] Miric, M, Ivkovic, S, Rajkovic, S, Markovic, M (2012). "Microscopical changing of the main Wood anatomical elements of Pedunculate and Sessile Oaks due to attack of the White rot fungus Chondrostereum purpureum (Pers. ex Fr.) Pouz.", Fresenius Environmental Bulletin, vol. 21, no 1, pp. 26-30

[19] Petrovic M (1980). Protection of wood 2, Scientific Book, Belgrade, p 440 [In Serbian].

[20] Rayner ADM, Boddy, L (1998). Fungal decomposition of Wood, Its Biology and Ecology, A Willey - Interscience Publication, Avon

[21] Schmidt O (1994). Holz und Baumpilze, Biologie, Shaden, Schutz, Nutzen, Springer - Verlaf. Berlin - Heidelberg, pp 48

[22] Soskic, B (1994). "Wood Properties", Book of Faculty of Forestry, University of Belgrade, Belgrade [In Serbian]

[23] SRPS D.A1.040:1979 "Testing of the wood, Taking specimens ISS" [In Serbian]

[24] SRPS D.A1.058 "Protection of the wood, Test for resistance to the fungus", ( Official Gazette No. 36/09: Ordinance on the technical and other requirements in the forestry and wood processing industry) [In Serbian].

[25] Tomic, Z (1992). "Forest phytocenoses in Serbia" ["Sumske fitocenoze u Srbiji”], Book of Faculty of Forestry, Belgrade, pp. 26

[26] Vucetic J (1998). Microbiological synthesis of antibiotics, the First Part of a General, Second Revised Edition, Velarta, Belgrade, p 168 [In Serbian]. 


\title{
REDUCTION THE MECHANICAL PROPERTIES OF OAKWOOD UNDER THE INFLUENCE OF EPYXILOUS FUNGUS
}

\author{
Miroslava MARKOVIC, Snezana RAJKOVIC, Ljubinko RAKONJAC
}

\section{Summary}

Within the scope of field research on diagnostics of harmful organisms in Serbia in the year 2015, in the area of Forest Estate Boljevac, the presence of epixylous fungus Coniophora puteana (Schumm. ex Fr.) Karst was found on dead oak trees following the icebreak. In order to give a more accurate forecast of prospective spread of the pathogen, i.e. determine the speed of the process, the laboratory of the Institute for Forestry conducted the testing of the rate of reduction of the oak tree modulus of elasticity after 2, 4 and 6 months of exposure to the fungus causing cubical brown rot on oak Coniophora puteana. Testing samples were collected from the medulla of healthy oak trees, from the association of Quercetum montanum. Over the periods of 2, 4 and 6 months the wood samples were exposed to influence of the mycelia of the fungus Coniophora puteana (Schumm. ex Fr.) Karst. Results of the research have demonstrated that the lowest dispersion of data (coefficient of variation) occurred in the control group of samples (18.35), while the highest was after 2 and 6 months of exposure to C. puteana (28.78 and 31.82), which is a consequence of the non-homogenous wood structure and uneven colonization of wood by the fungus. After 2, 4 and 6 months under the effect of the fungus, the static modulus of elasticity of oak wood substantially decreased compared to the initial value (100\%) and amounted to $61.07 \%, 60.61 \%$ and $51.38 \%$ respectively. The regression line obtained through data processing opened the possibility to prognosticate the changes of wood properties in certain time periods of the effect of the fungus under the unchanged external conditions, which is significant for practical purposes in terms of taking protective measures and wood usability.

\section{СМАҢЕЊЕ МЕХАНИЧКИХ СВОЈСТАВА ДРВЕТА ХРАСТА ПОД УТИЦАЈЕМ ЕПИКСИЛНИХ ГЉИВА}

\author{
Мирослава МАРКОВИЋ, Снежана РАЈКОВИЋ, Љубинко РАКОЊАЦ
}

\section{Резиме}

У оквиру теренских истраживања на пословима дијагностике итетних организама у Србији у 2015. години, на подручју ШГ Бољевач, на мртвом дрвету храста после ледолома, констатовано је присуство епиксилне гљиве Cопіорhоra puteana (Schumm. ex Fr.) Karst. Да ширења овог патогена, односно утврдила брзина тог процеса, у лабораторији Института за иумарство, извршена су испитивања брзине смањења једног механичког својства дрвета (чврстоће на савијање) након 2, 4 и 6 месеци излагања дејству ове гљиве. Испитивања су вршена на здравом дрвету храста из асоиијаџије Quercetum топtапит, након 2, 4 и 6 месеци излагања дејству гљиве која проузрокује мрку призматичну трулеж - Coniophora puteana (Schumm. ех Fr.) Karst. Резултати истраживања показују велико расипање података (варијаџиони коефицијент) у контролној групи узорака (18,35), а након 2 и 6 месеции дејства гљиве C. puteana износе $(28,78$ и 31,82), ито је последица нехомеогене структуре дрвета и колонизације под дејством гљиве. После 2, 4 и 6 месеци дејства гљиве, статичка чврстоћа на савијане храста у односу на иницијалне вредности 
(100\%) износи 61,07\%, 60,61\% и 51,38\%. Регресиона линија отвара могућност прогнозе промене својстава дрвета у одређеном времену дејства под утииајем гљива, при непромењеним условима спољне средине, ито је веома значајно у практичној примени, особито приликом заштите дрвета у ичљу очувања юегове употребне вредности. 